\title{
Formal Process of Managerial Learning: Empirical Evidence from Apparel Manufacturing Industry
}

\author{
V. Wickramasinghe
}

\begin{abstract}
This paper reports results of an empirical investigation into the formal processes that apparel manufacturing companies use to develop their managers. The findings of the study shed light on the formal development processes that are commonly used in the industry and on differences across companies of different ownership. The investigations revealed that not all human resource managers actively engage in the provision of different formal management development processes. Instead, some development processes are solely provided by the heads of the departments within their departments without having any specific organisation-led development initiative. The implications of the findings are discussed.
\end{abstract}

Key words: Apparel Industry, Management Development, Ownership

\section{Introduction}

The environmental factors have been changing theorists and practitioners' views on competitiveness and organisations have realised that competitive advantages are internal to the organisation (Ulrich and Lake, 1990). In the international business context too learning, knowledge acquisition and adaptation are important rationales for creating and managing successful international business organisations (Lyles and Salk, 1996). Organisations can adopt two human resource management (HRM) practices to enhance managerial skills- organisations can buy skills through selection or can improve the quality of current managers by providing management development (MD) programmes (Delanney and Huselid, 1996; Olian et al, 1998). In the latter case, considerable evidence suggests that investment in MD produces beneficial organisational outcomes (Knoke and Kallaberg, 1994; Russel et al, 1985). Thus, by understanding the value of MD, the theorists and practitioners suggest that organisations should actively undertake measures to develop their managers. Therefore, the main purpose of this investigation is to examine formal processes that apparel manufacturing industry in Sri Lanka uses to develop their managers.

Formal MD processes are institutionally sponsored, planned and deliberate processes, which are often monitored and controlled by people and forces other than the individual manager involved (Marsick and Watkins, 1997; Mumford, 1997). The processes such as, coaching, action learning groups, project assignments, job rotation and self development are identified as the constituents of formal processes of MD (Armstrong, 1999; Mole, 2000; Mumford, 1997; Mumford et al, 1987; Peel, 1984; Storey, 1994; Woodall, 2000). Though there are varieties of MD processes that can be used, none of the processes are 
superior to others. However, it is important to select and use appropriately different formal processes than wedded to a single one (Huczynski, 1993; Wills, 1998).

As informal processes are by products of organisational activities such as task accomplishment or interpersonal interaction, managers may not set out intentionally and explicitly to learn something through pre-planned means (Armstrong, 1999; Marsick and Watkins, 1997; Mumford, 1997). Therefore, there are major deficiencies in total reliance on informal processes, which emphasise the value of formal MD processes (Mumford, 1997). First, carefully acquired experience of how to do a managerial job may well become out of date. Second, closest relationships with bosses and colleagues may be excellent providers of advice and good models of effective behaviour- or they may be neither. Third, though people develop skills from the "natural" processes of doing the job and finding out whether the way they do it works, the skills they have acquired may be inappropriate and at worst it may even be the wrong kind of skills. Finally, it is possible for a manager's work experience to be extremely narrow in terms of jobs, functions, and kinds of organization and sizes of organization, but this does not mean that a manager should not learn about general aspects of management. Therefore, in MD, formal processes play an important role.

In Sri Lanka, it is accepted that human resource has and will continue to play a significant role in the global competition. The introduction of open economic policies in 1977 has made a significant impact on the realisation of the importance of MD as a major factor in the organisational process. The Sri Lankan literature suggests that with the advent of the open economy, the enhancement of organisational effectiveness has become a matter of vital importance in meeting complex demands of the new business environment. Therefore, organisations have taken concrete measures to provide organise MD programmes (Central Bank of Sri Lanka, 2000; Department of National Planning, 1992).

However, Sri Lankan literature on organisational practices suggests that companies mainly perceive human resource development (HRD) as a short-term activity that aims at providing the employees with bare minimum skills required for executing tasks assigned to them. Therefore, the main focus of HRD programmes was limited to those specific skills and disciplines that had an immediate and direct relevance to the employees' job performance (Chandratilake, 1997; Fonseka, 1998; Gunawardana, 1999; TT\&SC, 1999; Wijetunge, 1992). Further, it is found that many organisations have over emphasised the importance of off-the-job development programmes and most organisations rely on publicly run year round courses in developing their personnel (Fonseka, 1998; Wijetunge, 1992).

In the Sri Lankan apparel manufacturing industry context, by early 1990s, in-company development programmes were primarily focused on the operator level employees with little emphasis on upgrading managerial skills (Fonseka and Fonseka, 1998). However, the ever-changing technologies demand higher skills, not only at the operational level but also at the managerial level, both in improving technical and behavioural skills (Tennekoon, 1998; TT\&SC, 1999). The recent literature suggests that the importance given to 
development aspects of human resource by the Sri Lankan apparel manufacturing industry has been increasing (Gunawardena, 1999; Thennekoon, 1998). With the establishment of considerable number of foreign owned companies and joint venture companies, new systems of management have been "imported", which were alien to the indigenous industrial set-up of the country (Thennekoon, 1998). Further, attitudes in managing human resource are somewhat different in these foreign owned apparel manufacturing companies; they have started to develop human resource having identified it as a key to improvements in the industry (Gunawardena, 1999). Therefore, it can be assumed that they might have brought in their own MD practices challenging and changing the nature of prevalent practices in the Sri Lankan private sector. In this context, apart from the contribution made by joint venture and foreign owned companies to the economic growth of the country, they have brought into Sri Lanka not only modern plants and equipment, but also management expertise and practices.

\section{The Context of the Study: The Sri Lankan Apparel Manufacturing Industry}

Sri Lanka has faced severe challenges in the sphere of industrialisation since 1948. With high unemployment and insufficient indigenous capital, the attraction of foreign investment became a major priority. Having realised the benefits of foreign direct investment, there has been a firm commitment to maintain open economic policies and to further strengthen the market friendly economic policy framework that existed since 1977 (Central Bank of Sri Lanka, 1998). On the other hand, in response to several reasons such as increasing global competition, lower labour cost in Sri Lanka and inducements from the Sri Lankan government, the number of international businesses coming into Sri Lanka has been increasing since 1977 .

With the introduction of open economic policies, new investment opportunities have been created in manufacturing, trade, services, and construction industry. Thus, sectoral composition of the GDP has also undergone significant changes. Meanwhile, the manufacturing and export structures have become diversified with new export items such as, apparel, successfully entering into international markets (Central Bank of Sri Lanka, 1998). Though Sri Lanka first began to promote the apparel manufacturing industry as an import substitution industry during 1960, the period after the late 1970s saw a rapid expansion in the industry. Given the easy separability of the apparel manufacturing industry into different stages, overseas producers have been able to disintegrate their production lines into low production cost countries such as Sri Lanka, without much difficulty (Karunatilake, 1999; Senanayake, 2001; Waidyanatha, 1999). In the circumstances, investment by East Asian and European manufacturers fuelled the growth of the Sri Lankan apparel manufacturing industry. At present, apart from the wholly local owned companies(used as "local" throughout this paper), several apparel manufacturing companies have been set up in Sri Lanka as wholly foreign owned companies (used as "foreign" throughout this paper) and as local and foreign joint venture companies (used as "joint venture" throughout this paper). These foreign and joint venture companies can be, further, classified by the continent of origin as shown in table 1 . 
Table: 1 Ownership of the Companies by the Continent of Origin

\begin{tabular}{|c|c|}
\hline Continent of origin & Number of companies \\
\hline \multicolumn{2}{|c|}{$100 \%$ foreign to Sri Lanka $=68$} \\
\hline European & 12 \\
\hline American & 2 \\
\hline Asian & 48 \\
\hline Mix of continents & 7 \\
\hline \multicolumn{2}{|c|}{ Joint ventures with Sri Lankans $=57$} \\
\hline European & 14 \\
\hline American & 5 \\
\hline Asian & 32 \\
\hline Mix of continents & 6 \\
\hline
\end{tabular}

Source: BOI, 2000b

As the number of foreign companies that come into Sri Lanka increased, the foreign investments contribution to the economy also increased. For instance, in 1979, there were total 9 apparel manufacturing companies with foreign investment of Sri Lankan Rupees Million 68.0 (includes investment of wholly foreign owned companies and foreign investment component of the foreign/local joint venture companies) and local investment of Sri Lankan Rupees Million 58.3 (includes investment of wholly local owned companies and local investment component of the foreign/local joint venture companies). By 1989, a decade latter, there were total 43 apparel manufacturing companies with foreign investment of Sri Lankan Rupees Million 2372.8 and local investment of Sri Lankan Rupees Million 1111.8. Two decades latter, by October 2000, there were total 207 apparel manufacturing companies with foreign investment of Sri Lankan Rupees Million 12126.4 and local investment of Sri Lankan Rupees Million 11054.5 (BOI, 2000a). The above figures show how foreign investment has increased over time. In the mean time, this industry has become the leading manufacturing and export industry in Sri Lanka by 1990s and the country's largest single employment provider in the industrial sector. Hence, policy makers of today have placed heavy emphasis on the apparel manufacturing industry as a means of promoting employment and generating foreign exchange earnings and as the main contributor to the overall economic development.

\section{Objectives of the Study}

Literature suggests that there are number of different and equally successful ways of organising management in the market economy (Chen, 1995; Whitley, 1994). Further, when companies locate their businesses abroad, they retain and transfer the unique sets of management practices that they are accustom to, which are reflected in specific management structures, decision-making processes, etc (Sparrow et al, 2000). Therefore, it can be expected that there will be significant differences in MD practices across the apparel manufacturing companies of different ownership. Further, it is documented in the literature on international management that host country business partners can learn from their joint venture partners, and may have access to knowledge that would not have been available in the absence of collaboration. Further, this knowledge transfer has primarily 
occurred in the areas of manufacturing processes and HRM (Inkpen and Dinur, 1998; Liu and Vince, 1999; Schuler, 2001). Therefore, it can be assumed that foreign companies might have brought in their own practices challenging and changing the nature of prevalent practices in the Sri Lankan private sector.

In widening a firm's strategic focus beyond the confines of its national boundaries, the human element becomes paramount (Bournois and Metcalfe, 1991). However, attention has been mainly devoted to international comparisons of production systems, and comparison of HRM systems has until recently been overlooked (Sparrow et al, 2000). Similarly, although there has been much scholarly and popular debate on the transfer of management practices in the context of Europe and America, less attention has been paid to Asian countries (Cunningham et al, 1996; Taylor, 2001). On the other hand, though there are studies on transfer of knowledge, the main emphasis has been placed on how organisations involved in alliances can use their alliance experience as a basis for managing and creating knowledge and on knowledge management processes in creating and establishing joint ventures (Griffith et al, 2001; Inkpen and Beamish, 1997; Inkpen and Dinur, 1998; Liu and Vince, 1999). However, lack of attention has been paid to understand differences in MD practices and transfer of MD practices with the foreign investment. Specifically none of the studies have been conducted in the context of Sri Lanka, where international business operations have been increasing and have a high profile. Therefore, this study aims to fill this gap in the literature by investigating formal MD processes used by the apparel manufacturing companies and identifying differences across companies of different ownership. And by doing so determine the extent to which formal MD processes are utilized in the Sri Lankan context.

Within the above context, to guide this study two research questions have been raised. First, if the purpose of providing managers with development programmes is mainly to assist in the attainment of organisational objectives, then what has to be learnt can not be left purely to chance. A good deal of dissatisfaction remains with the state of MD research revolving around lack of detailed information about the formal processes by which development takes place in organizations (Thomson et al, 1998). Further, research requires re-examine recent evidence claiming a growing use of MD in workplaces to help managers learn (Woodall 2000). Therefore, it is questioned that what formal MD processes are used by the apparel manufacturing companies and to what extent those companies differ in terms of ownership in the usage of formal MD processes. For the investigation, formal MD processes are categorised into four main groups, namely, job redesign methods (such as, job rotation), on-the-job methods (such as, coaching), off-thejob methods (such as, attendance at conferences) and self-development methods (such as, provision of library facilities) that are sponsored by the organisations. Further, in gathering data, human resource (HR) managers' views were explored to find out their experiences in providing formal MD processes while managers' views were explored to find out their experiences in receiving these. The study sought to identify differences and similarities across local, foreign and joint venture companies. This is based on the assumption that because foreign companies transfer their management practices abroad, certain differences 
would be found across companies of different ownership. Therefore, following are hypothesised.

Hypothesis 1: There will be significant differences across ownership types regarding the provision of different formal development processes by HR managers. It is expected that HR managers from foreign companies will be more likely to be involved in providing varieties of formal development processes for managers than that of HR managers from other two types of ownership (i.e., local and joint venture).

Hypothesis2: There will be significant differences across ownership types regarding experiencing different formal development processes by managers. It is expected that managers from foreign companies will be more likely to experience varieties of formal development processes than that of managers from other two types of ownership (i.e., local and joint venture).

Second, it is documented in the literature that when companies locate their businesses abroad, they retain and transfer their unique sets of management practices across cultures providing a platform for organisational learning, giving access to skills and capabilities of partners. By considering the changes that have been occurred since 1977 in the ownership of the companies, it can be assumed that the entrance of global enterprises into the country has an enormous influence on HRD practices. International businesses operate as foreign and joint venture companies. Therefore, it is questioned whether foreign and joint venture companies brought into Sri Lanka their practices and how significant the differences are across companies of different ownership.

\section{Population and Sample}

\section{Methodology}

The apparel manufacturing companies registered under Board of Investment of Sri Lanka (BOI) served as the population of the study. There are three main reasons in selecting this as the study population. First, BOI is the primary government authority responsible for identifying, promoting and facilitating both foreign and local investments in Sri Lanka (BOI, a) and apparel manufacturing is the major industrial category under BOI (BOI, a). Second, it is compulsory by law that all foreign investments (wholly foreign owned and foreign/local joint venture) should come into the country through BOI (BOI, a; BOI, b). Therefore, this provides easy and systematic access to foreign and joint venture companies. Third, it is compulsory by law that all BOI registered companies should export at least 90 percent of the manufactured output (BOI, a; BOI, b). Thus all local companies, foreign companies and joint venture companies that come under this study population are homogeneous in nature in terms of business operations.

At the time of the study there were 207 ( 82 local, 68 foreign, 57 joint venture) apparel manufacturing companies registered under BOI. From the study population, a proportionate stratified random sample of 100 companies based on ownership type was initially obtained. In selecting a sample of 100 companies, initial contacts were made over 
the telephone using the random sample method within each stratum until the required number of companies, for each stratum, agree to participate in the study. There are disadvantages of collecting survey data from one source; researchers are encouraged to collect data using several sources (Ichniowski et al, 1996; Nichols, 1986). Therefore, from these 100 companies, $100 \mathrm{HR}$ managers and 400 Managers were selected. There were no problems in selecting the sample of $100 \mathrm{HR}$ managers as there is only one HR manager per each randomly selected company. In selecting a sample of 400 managers, initial contacts were made using simple random sample method with 4 managers who are not working in the same managerial function in the 100 companies previously selected (100x4). Table 2 provides information on the stratification of the populations and how they were proportionately broken down into a sample of $100 \mathrm{HR}$ managers and 400 managers.

Table: 2 Stratification of the Study Population

\begin{tabular}{|l|c|c|c|c|}
\hline $\begin{array}{l}\text { Ownership of } \\
\text { the company }\end{array}$ & $\begin{array}{l}\text { No. of } \\
\text { companies in } \\
\text { the population }\end{array}$ & $\begin{array}{l}\text { Proportion of } \\
\text { companies for } \\
\text { each strata }\end{array}$ & $\begin{array}{l}\text { Proportion of } \\
\text { HR mangers } \\
\text { for each strata }\end{array}$ & $\begin{array}{l}\text { Proportion } \\
\text { of mangers } \\
\text { for each } \\
\text { strata }\end{array}$ \\
\hline Local & 82 & 40 & 40 & 160 \\
\hline Foreign & 68 & 33 & 33 & 132 \\
\hline Joint venture & 57 & 27 & 27 & 108 \\
\hline Total & 207 & 100 & 100 & 400 \\
\hline
\end{tabular}

However, due to various reasons, the total number of responses obtained from HR managers amounted to 78 instead of 100; the total number of responses obtained from managers amounted to 219 instead of 400. The actual number of HR managers and managers that had participated in the study are shown in table 3. As can be seen from the table, the number of HR managers in each category (local, foreign, joint venture) of the sample consisted of more than 35 per cent of the HR managers in each category of the population (for example, HR managers from local companies: $32 / 82 \times 100=39 \%$ ). Further, the number of managers in each category (local, foreign, joint venture) of the sample consisted of more than 46 per cent of the managers in each category of the population (for example, managers from local companies: 104/160x100=65\%).

Table: 3 Classification of Respondents in terms of Ownership

\begin{tabular}{|l|c|c|c|c|}
\hline \multirow{2}{*}{$\begin{array}{c}\text { Ownership of the } \\
\text { company }\end{array}$} & \multicolumn{2}{|c|}{$\begin{array}{c}\text { Respondents to } \\
\text { questionnaire }\end{array}$} & \multicolumn{2}{c|}{ Respondents to interview } \\
\cline { 2 - 5 } & $\begin{array}{l}\text { HR } \\
\text { managers }\end{array}$ & Managers & $\begin{array}{l}\text { HR } \\
\text { managers }\end{array}$ & Managers \\
\hline Local & 32 & 104 & 7 & 10 \\
\hline Foreign & 26 & 65 & 6 & 8 \\
\hline Joint venture & 20 & 50 & 5 & 7 \\
\hline Total & 78 & 219 & 18 & 25 \\
\hline
\end{tabular}




\section{Methods of Data Collection}

There are several ways of conducting social research, such as experiments, surveys, case studies, histories and the analysis of archival information (Yin, 1994). The selection of a research method depends on purpose and nature of the study. This study is exploratory as well as descriptive in nature. Hence questionnaire method complemented with structured interviews was chosen in order to capture the two dimensions of the investigation (Yin, 1994). In the study two different perspectives on formal MD processes were probed using two set of samples- HR managers and managers of the apparel manufacturing companies. Hence, two different survey questionnaires were prepared. As shown in table 3, $78 \mathrm{HR}$ managers (32 local, 26, foreign, 20 joint venture) and 219 managers (104 local, 65, foreign, 50 joint venture) responded to the self-administrated questionnaires. Semistructured interviews were deemed necessary to complement the survey questionnaires. Therefore, two separate interview guides were developed to corroborate the information that had been gathered from the survey questionnaires and to elaborate the field by exploring a greater variety of experiences offered by HR managers and managers. 25 managers (10 local, 8, foreign, 7 joint venture) and 18 HR managers ( 7 local, 6 foreign, 5 joint venture) from the stratified random sample willingly agreed to participate in the interviews.

On one hand, selection of a larger sample using proportionately stratified random sample method help to estimate population parameters of the aspects under study. Further, the investigation was carried out based on the information collected from multiple instruments- questionnaires and interviews. Furthermore, to maintain consistency throughout, in administering both instruments, same questions were asked from all respondents. These helped to maintain reliability of the instruments. On the other hand, questionnaire and interview items were selected after thorough review of literature; items were designed only to measure that particular aspect and not something else. Further, both questionnaires and interview guides were reviewed by academics and professionals in the field of conducting survey based research and HRD (researcher especially acknowledge the guidance received from Cathy-Marsh Centre for Survey Research at University of Manchester, UK). The both questionnaires and interview guides were pilot tested in Sri Lanka and made necessary alterations to improve the reliability and face validity.

\section{Data Analysing Techniques}

In testing hypothesis, analysis of variance (ANOVA) was used. Hypotheses were tested at the 95 per cent confidence level. In the research design no participant took part in more than one level of the treatment factor. The companies that stated "local" in terms of ownership are independent of the other two ownership categories, therefore, betweensubjects ANOVA design was used (Brace et al, 2000, Bryman and Cramer, 2001, Runyon et al, 2000). Respondents' comments were categorised and incorporated into the discussion of the survey results. 


\section{Characteristics of the samples}

\section{Analysis}

The information provided by the HR managers was used to identify certain characteristics of the companies in which they have been employed in. These characteristics are identified in terms of number of managers employed in the companies, number of employees in the companies and existence of a HRD department/unit. With regard to the number of managers employed in the companies, 59 per cent of the companies have employed more than 10 managers. 82 per cent of the companies have employed less than 1001 employees. 52 per cent of the companies have HRD units.

Based on the information provided by the managers, the characteristics of the managers represented in the sample are identified in terms of gender, age, academic qualifications, etc. with regard to gender, 78 per cent is Male. This high percentage of males in the sample is a common occurrence (Gunawardena, 1999). With regard to the age distribution of managers, 89 per cent is below 41 years of age. With regard to the educational attainment of managers, 43 per cent has degrees or equivalent academic qualifications; 25 per cent has Diplomas. With regard to professional qualifications, 76 per cent of the sample is professionally qualified. With regard to the years of service of managers, 77 per cent is with their current employer as a manager for less than five years. With regard to the level of management they are employed in, 45 per cent of the managers come from the middle level management. However, the number of managers from the each category of lower level and middle level management consisted of more than 20 per cent of the sample. With regard to the ownership of the companies in which managers are employed in, 48 per cent of the managers are employed in local companies. With regard to the existence of HRD department/unit in the companies in which managers are employed in, 52 per cent come from companies that have separate HRD department/unit.

\section{Findings and Discussion}

First, HR managers' experiences in providing different formal MD processes were probed by asking a set of questions on a Likert type five-point scale. Their responses are shown in table 4.

Table: 4 Provision of Formal MD Processes for Managers (in percentages)

\begin{tabular}{|l|l|l|l|l|l|l|l|l|}
\hline Item & Always & Often & $\begin{array}{l}\text { Some } \\
\text { times }\end{array}$ & $\begin{array}{l}\text { Almost } \\
\text { never }\end{array}$ & Never & Total & Mean & STD \\
\hline $\begin{array}{l}\text { Job redesign } \\
\text { methods }\end{array}$ & 5.1 & 19.2 & 32.1 & 34.6 & 9.0 & 100 & 2.77 & 1.03 \\
\hline $\begin{array}{l}\text { On-the- job } \\
\text { methods }\end{array}$ & 12.8 & 43.6 & 30.8 & 7.7 & 5.1 & 100 & 3.51 & 0.99 \\
\hline $\begin{array}{l}\text { Off-the-job } \\
\text { methods }\end{array}$ & 20.5 & 34.6 & 29.5 & 10.3 & 5.1 & 100 & 3.55 & 1.09 \\
\hline $\begin{array}{l}\text { Self-development } \\
\text { methods }\end{array}$ & 2.6 & 22.1 & 33.8 & 24.7 & 16.9 & 100 & 2.69 & 1.08 \\
\hline
\end{tabular}


The data shown in table 4 suggests that companies are more likely to provide "off-the-job methods" ( $\overline{\mathrm{X}}=3.55)$ followed by "on-the- job methods" $(\overline{\mathrm{X}}=3.51)$. In fact, the mean difference between the two categories is negligible (0.03). However, "redesigning jobs" for development purposes $(5.1 \%)$ and encouraging managers for "self-development methods" $(2.6 \%)$ are not popular. These findings are consistent with Chandratilake (1997) who found that export manufacturing companies at managerial levels provided broad onthe-job development programmes together with off-the-job in-house development programmes. Companies also provide off-site development programmes arranged through both local institutions, and tailor made programmes and workshops arranged at various intervals on off-the-job in-house basis. Further, these findings are consistent with the findings of Storey et al (1997) that MD in Britain was frequently seen as a matter of "going on courses". Furthermore, these findings are consistent with the findings of Lawler et al (1995) that HR managers in Thailand were less apt to use on-the-job development methods and more apt to use off-the-job development methods. However, these findings are not consistent with Storey et al's (1997) observations in Japan. Though there is an increased recognition that self-development is an important concept in the whole programme for MD (Beach, 1975; Handy, 1987; Romiszowski, 1990), in the Sri Lankan context self-development methods provided by the companies are not popular.

To determine variation in the provision of formal MD processes for managers, hypothesis 1 is tested. The results are shown in table 5.

Table: 5 ANOVA of Provision of Formal MD Processes for Managers

\begin{tabular}{|l|l|l|l|l|l|}
\hline \multirow{2}{*}{ Item } & \multicolumn{3}{|c|}{ Mean } & F & \multirow{2}{*}{ Sig. } \\
\cline { 2 - 7 } & Local & Foreign & $\begin{array}{l}\text { Joint } \\
\text { venture }\end{array}$ & \\
\hline Job redesign methods & 2.28 & 3.12 & 3.10 & 7.032 & 0.002 \\
\hline On-the- job methods & 3.13 & 3.73 & 3.85 & 4.646 & 0.013 \\
\hline Off-the-job methods & 3.56 & 3.54 & 3.55 & 0.003 & 0.997 \\
\hline Self-development methods & 2.09 & 2.96 & 3.25 & 10.179 & 0.000 \\
\hline
\end{tabular}

The results reveal that there are no significant differences across companies of different ownership in providing off-the-job methods. However, there are significant differences across companies in providing other three types of formal development processes. Therefore, the Least Significant Differences (LSD) are computed to compare each group with every other group and computed the significance of the difference. The results showed that foreign and joint venture companies are more likely to provide "on-the-job methods", to use "job redesign methods" and "self-development methods" that are sponsored by the companies for managers than that of the local companies. Further, the mean values shown in table 5 also confirm this. On the other hand, there are no significant differences between foreign and joint venture companies in the provision of any of the formal development processes. Hence, hypothesis is partially accepted. 
As total reliance on one group of respondents leads to bias, views of managers on receiving company sponsored formal MD processes were also explored. Their responses are shown in table 6.

Table: 6 Managers' Experiences of Receiving Formal MD Processes

\begin{tabular}{|l|l|l|l|l|l|l|l|l|}
\hline Item & Always & Often & $\begin{array}{l}\text { Some } \\
\text { times }\end{array}$ & $\begin{array}{l}\text { Almost } \\
\text { never }\end{array}$ & Never & Total & Mean & STD \\
\hline $\begin{array}{l}\text { Job redesign } \\
\text { methods }\end{array}$ & 13.1 & 25.0 & 26.4 & 12.7 & 22.8 & 100 & 2.902 & 1.001 \\
\hline On-the- job methods & 7.5 & 21.9 & 26.0 & 18.5 & 26.1 & 100 & 2.639 & 1.064 \\
\hline Off-the-job methods & 8.2 & 18.8 & 24.1 & 16.5 & 32.4 & 100 & 2.422 & 1.445 \\
\hline $\begin{array}{l}\text { Self-development } \\
\text { methods }\end{array}$ & 4.9 & 9.4 & 15.4 & 18.7 & 51.6 & 100 & 1.886 & 1.243 \\
\hline
\end{tabular}

The data shown in table 6 suggests that managers are more likely to experience "job redesign methods" ( $\overline{\mathrm{X}}=2.9)$ followed by "on-the-job methods" $(\overline{\mathrm{X}}=2.63)$. The mean difference between the two categories is 0.27 . Managers have ranked "self-development methods" last.

To determine variation in experiencing formal MD processes by managers, hypothesis 2 is tested. The results are shown in table 7.

Table 7: ANOVA of Experiencing Formal MD Processes by Managers

\begin{tabular}{|l|l|l|l|l|l|}
\hline \multirow{2}{*}{ Item } & \multicolumn{3}{|c|}{ Mean } & F & \multirow{2}{*}{ Sig. } \\
\cline { 2 - 6 } & Local & Foreign & $\begin{array}{l}\text { Joint } \\
\text { venture }\end{array}$ & & \\
\hline Job redesign methods & 2.912 & 2.926 & 2.850 & 0.092 & 0.912 \\
\hline On-the- job methods & 2.590 & 2.658 & 2.715 & 0.241 & 0.786 \\
\hline Off-the-job methods & 2.319 & 2.465 & 2.555 & 0.531 & 0.589 \\
\hline $\begin{array}{l}\text { Self-development } \\
\text { methods }\end{array}$ & 1.649 & 2.092 & 2.110 & 3.682 & 0.027 \\
\hline
\end{tabular}

The results reveal that there are no significant differences across companies of different ownership in managers receiving "job redesign methods", "on-the-job methods" and "offthe-job methods". However, there are significant differences across companies in experiencing self-development methods sponsored by the companies. The results of the LSD showed that managers in foreign and joint venture companies are more likely to experience "self-development methods" provided by the companies than that of managers in the local companies.

When managers' responses and HR managers' responses are compared, HR managers stated that companies most often provide off-the-job methods, but managers' responses reveal that they experience job redesign methods most often. As there are differences in the HR managers' responses for providing (table 4) and managers' responses for receiving 
formal MD processes (table 6), managers' responses were in-depth analysed. Their responses are shown in table 8.

Table: 8 Detailed Breakdown of Formal MD Processes experienced by Managers (in percentages)

\begin{tabular}{|l|l|l|l|l|l|l|l|}
\hline Item & Always & Often & $\begin{array}{l}\text { Some } \\
\text { times }\end{array}$ & $\begin{array}{l}\text { Almost } \\
\text { never }\end{array}$ & Never & Mean & STD \\
\hline \multicolumn{7}{|c|}{ Job redesign methods } \\
\hline Job rotation & 9.3 & 10.3 & 24.8 & 15.9 & 39.7 & 2.34 & 1.34 \\
\hline $\begin{array}{l}\text { Given more responsibilities } \\
\text { to learn }\end{array}$ & 17.1 & 41.2 & 24.5 & 5.1 & 12.0 & 3.46 & 1.19 \\
\hline Work in special groups & 12.5 & 27.3 & 26.4 & 15.7 & 18.1 & 3.00 & 1.29 \\
\hline $\begin{array}{l}\text { Assignments in committees/ } \\
\text { task groups }\end{array}$ & 13.5 & 21.4 & 29.8 & 14.0 & 21.4 & 2.92 & 1.32 \\
\hline \multicolumn{7}{|c|}{ On-the- job methods } \\
\hline Coaching & 7.0 & 20.2 & 30.5 & 17.4 & 24.9 & 2.67 & 1.47 \\
\hline Counselling & 5.6 & 20.9 & 23.3 & 20.0 & 30.2 & 2.52 & 1.27 \\
\hline Mentoring & 11.0 & 21.7 & 24.0 & 18.0 & 25.3 & 2.84 & 1.55 \\
\hline Action learning & 7.4 & 24.7 & 25.6 & 18.6 & 23.7 & 2.73 & 1.27 \\
\hline \multicolumn{7}{|c|}{ Off-the-job methods } \\
\hline In-company programmes & 10.6 & 23.5 & 25.3 & 19.4 & 21.2 & 2.83 & 1.29 \\
\hline $\begin{array}{l}\text { External courses such as, } \\
\text { Diploma, MBA, }\end{array}$ & 7.9 & 17.1 & 22.2 & 14.8 & 38.0 & 2.42 & 1.35 \\
\hline $\begin{array}{l}\text { Attendance at seminars/ } \\
\text { conferences }\end{array}$ & 13.0 & 29.6 & 26.9 & 14.4 & 16.2 & 3.09 & 1.27 \\
\hline Distance learning & 1.4 & 5.1 & 22.0 & 17.3 & 54.2 & 1.82 & 1.03 \\
\hline
\end{tabular}

The data shown in table 8 suggests that the majority of managers have experienced "adding more responsibilities to learn" $(\bar{X}=3.46)$. The second most experienced form is "attending at seminars and conferences" $(\overline{\mathrm{X}}=3.09)$. With regard to on-the-job methods, "mentoring" ( $\bar{X}=2.84)$ and "action learning" $(\bar{X}=2.73)$ have been experienced by the majority of managers. Within the category of off-the-job methods, in-company programmes have been experienced by the majority of managers $(\bar{X}=2.83)$. However, "attendance at external courses" is ranked $10^{\text {th }}(\overline{\bar{X}}=2.42)$. When the data shown in table 8 is compared with other studies conducted in Sri Lanka, the data is not consistent with the findings of Fonseka (1998), or Wijetunge (1992). They observed that managers experienced a limited number of formal MD processes mainly through off-the-job methods. However, none of those studies are conducted in the apparel manufacturing industry. Further, the data shown in table 8 is not consistent with Lawler et al's (1995) observation in Thailand and Storey et al's (1997) observation in Britain as they revealed that formal processes to a greater extent rely on "courses" provided by outside vendors. 
However, the findings are consistent with the findings of Henderson et al (2000) and Avery et al (1999) as this study also reveals that attendance at short courses or seminars on specific topics have often experienced by managers (ranked $2^{\text {nd }}$ ). Though Institute of Management, UK (1994) observed a trend towards a greater preference for coaches and mentors, in this Sri Lankan study those are not highly ranked $\left(5^{\text {th }}\right.$ and $6^{\text {th }}$ respectively). "Distance learning" is the least experienced method $\left(\bar{X}=1.82\right.$, ranked $\left.14^{\text {th }}\right)$. With regard reading $(\bar{X}=1.99)$ and guided reflection $(\bar{X}=1.92)$, those received low responses. As a category, self-development methods are the least provided for and experienced by the managers. This is also visible from table 4 and 6.

The data shown in table 6 reveal that managers more frequently experience job redesign methods as a formal MD process. This is further confirmed by the data shown in table 8 as $1^{\text {st }}, 2^{\text {nd }}$, and $3^{\text {rd }}$ ranks of managers' responses belong to the job redesign methods. Thus, it can be concluded that managers most frequently experience job redesign methods as a formal development category. However, this contrasts with HR managers' responses as table 4 reveals that they frequently provide off-the-job methods. Therefore, during the interviews attention is paid to further probe managers' and HR managers' responses. It is observed that in some companies HR managers with the heads of the departments involve in providing on-the-job methods, job redesign methods, off-the-job methods and selfdevelopment methods. However, in some other companies development processes such as on-the-job methods, job redesign methods and self- development methods are solely provided by the heads of the departments within their departments. Therefore, managers in such companies are experiencing formal MD processes, which are not only provided by HR managers, but also by the initiation of managers' superiors. Most of such processes are designed and planned by the heads of departments without having any specific organisation led development initiative. However, in the companies that maintain certain level of consistency in providing these formal development processes, either with or without the initiation of the HR managers, managers have experienced these in daily organisational life. However, in the latter case, all managers might not have felt and experienced the same. The development activities that are initiated by the heads of departments are less likely to be deliberately planned or contrived for the purpose of shaping the developmental aspects of managers. Hence, it could assume that these are incomplete as formal MD processes and moreover incomplete in the areas of most crucial concern to managerial learning. The formal MD processes that are initiated without HR managers' involvement are "hidden"- not seen as one of the main routes to develop managers. Therefore, such development processes are restricted to the departments concerned. On the other hand, HR managers in such companies are busy in designing and planning off-the-job development processes, which are not highly ranked by the managers as their frequent formal development experiences. The HR managers of those companies regard that formal MD processes have to be based on off-the-job methods as education in Sri Lanka has traditionally been more instructor-oriented and less learner-oriented. If those HR managers had exposed to varieties of formal MD processes, MD would have been a mix of on-the-job methods, job redesign methods, off-the-job methods and selfdevelopment methods. All these may lead to find out differences across ownership types in table 5 . 
In answering the second research question, when Sri Lanka opened its door to foreign investment in 1977, those investors might have brought into Sri Lanka their practices and they retained and transferred those practices to their local operations to some extent, which lead to find higher mean values for foreign and joint venture companies than that of local companies in the provision of MD processes. However, though local companies have less frequently provided some of the formal MD processes they are not alien to them- they are also practising them to some extent. This could have led to find that managers from all the three types of ownership experience similar formal MD processes. This situation could be better described as being less "in degree" rather than "in kind". In this context, several aspects have emerged from the results of the investigations for the local companies' familiarity with current formal MD processes that are in use. And the design of the study made it possible to generalise these in a broader perspective to Sri Lankan organisations.

First, Veblen (1954) and Kerr et al (1960) argued that industrialisation would ensure that managerial attitudes, values and behaviour would become increasingly uniform. This has recently also been emphasised by Chen (1995), who showed that all the Asian management systems are currently undergoing a rapid process of modernisation, where companies drive to modernise its management by grafting foreign work practices; thus, systems are becoming more similar. In this connection, while business systems are competing in world markets, they have to adapt to dominant patterns in those markets. Thus, foreign management concepts enter into the play in the forms of the requirements of foreign buyers and international standards and those have a high degree of legitimacy. This situation is explicit in the Sri Lankan context. It should not be forgotten that all apparel manufacturers manufacture the products for the global market, which is mainly the US and the EU (Karunatilake, 1999). Though it is not compulsory, apparel manufacturers identify international standards of certification as a source of competitive advantage, especially to face recently entered countries to the apparel manufacturing industry. Though international standards do not specify requirements of HRD/MD in their standards, international standards have resulted in a growing awareness about HRD/MD. Further, in many cases, the first step organisations take towards provision of HRD/MD is to abide by ISO 9000 standards, which led to more universal HRD/MD practices. In this context, when whole conceptual framework of HRD/MD itself relatively recent and developed on the basis of implicit western assumptions (Hofstede, 1993), the countries have no choice but to use them, thus, having foreign features as the fundamental nature.

Second, as Whitley (1994) noted, internationalisation of markets and firms is not a simple matter of transferring managerial technologies to foreign subsidiaries, and thereby transforming "backward" economies. Thus, it is not a case of exporting their practices to host countries. Thus, building on previous theory and empirical evidence, the development of business systems in host countries, in particular the ability of multinationals to transplant domestic practices to overseas subsidiaries and establish them successfully there, depend on several organisational and environmental factors (Beechler and Yang 1994, Naylor 2000, Whitley 1994). In Sri Lanka, though there are several investors from the Asia Pacific region established companies in the industry, the study had 
not found any attempts made by those investors to introduce MD processes, such as job rotation with their original features as those are practiced in their home countries. Therefore, in the Sri Lankan context, three such aspects can be identified that could be working as constraints in establishing their original MD processes, which are a) the extent to which foreign multinationals' organisational structures and value systems have already converged (even before entering into Sri Lanka) and evolved some practices that are different to their original management practices, b) strength of current local practices and cohesion of institutions in Sri Lanka, c) the nature of apparel manufacturing industry, itself.

a) When considering the details of the countries of origin of apparel manufacturing companies that operate in Sri Lanka as wholly foreign owned companies, majority of them are joint venture multinational companies (for example, Hong Kong/German collaborations, South Korea/Hong Kong/USA collaborations). Further, foreign investment components of the local/foreign joint ventures also revealed a similar situation. The broad legislative differences between countries, differing political, cultural and social concerns create quite different conditions for HRM practices within these multinational companies, which influence the extent to which they will be able to practice their own original management practices in such multinationals. Therefore, examples of foreign investments like above operating in Sri Lanka emphasise that their organisational structures and value systems have already inevitably converged and evolved some practices that are different to their original management practices. This could work as a constraint in transferring original management practices of different management systems, such as Japanese and South Korean. In this context, as Whitley (1994) argued more a particular business system and its characteristics are mutually reinforcing, more difficult will they find it to alter established procedures and rationalities, therefore, they are less likely to adopt novel practices in foreign subsidiaries, could not be applied to the Sri Lankan context.

b) Strength of current local practices and cohesion of institutions in Sri Lanka could work as constraints in transferring management practices. Cohesion of local institutions may be due to the colonial legacy left by the British. The findings of Wijewardena and Wimalasiri (1996) show that due to the invasions of Western rulers, which had prevailed for hundreds of years, the indigenous management practices of Sri Lanka have disappeared and management practices brought by western rulers have become dominant. It is a fact that several centuries of British rule left its mark on the system of administration, industry and commerce in Sri Lanka. Policies were determined unilaterally by the colonial administrators and implemented through a network of administrative officials who were considered to be loyal to the authority. In addition to the total control over the administrative mechanism in the public sector, the private sector enterprises were placed under the foreign management. All major industries during the colonial rule such as tea, rubber, coconut, and spice were run by the foreign managers. Thus, even after the colonial period, the indigenous people had to follow the footsteps of running a 
business using western systems. Sri Lankan literature provides ample evidence for the influences of western colonial rule on administrative and managerial development since independence (Chinniah, 1986; Manuratna 1986; Minks and Withana, 1977; Nanayakkara, 1992). As the studies of Laburn (1994) and Lawler et al (1995) revealed in the context of South Africa, India and Thailand, the British colonial system had enormous influence on MD practices in the case of Sri Lanka. Therefore, though Bournois (1992) and Schein (1986) state that practices of management of human resource have to be derived from and strongly reflect the national culture of the country in which an organisation is located, in the Sri Lankan context, already available formal MD processes are closely related to the western world. In this context, in the construction of HRD/MD systems, the foreign investors have to rely on local industrial relations and personnel experts, which could lead foreign investors to adapt their operations to host country environments and alter policies in different ways depending on the issue. Therefore, local organisations that depict more uniform practices could work as a constraint in the transfer of management practices.

c) The nature of apparel manufacturing industry itself may be working as a constraint in the Sri Lankan context. The issues of addressing economic growth and industrialisation influence government strategies to attract foreign investment and modern technology. Though the strength and role of the state and foreign investment governing local institutions can often prevent the direct transfer of managerial practices (Beechler and Yang, 1994; Whitley, 1994), with minimum legal requirements from BOI, foreign investors are free to introduce their distinctive ways of MD. Another related point is that Sri Lanka being a smaller developing economy, foreign companies from dominant economies are in a strong position to bring in and operate their distinctive ways of MD. The significant feature of the apparel manufacturing industry is the easy separability of the manufacturing process into different stages and overseas investors have been able to disintegrate their production lines into low production cost countries, without much difficulty. This prompts a continuous search on the part of the investors for lower cost locations making it a "foot loose" or highly mobile industry. In this context, though there are less barriers from the Sri Lankan government and other legal institutions, foreign investors may not be prepared to spend sufficient time to transplant their MD processes in Sri Lanka. In such a situation, foreign investors' preferred MD processes have been tailored to meet business objectives conditioned by the global competitive environment.

By considering all these, although the data analysis revealed that both foreign and joint venture companies are more likely to attend to the provision of MD than local companies. This situation could be explained largely by organisational level factors rather than macro level factors such as the economic, historical and global environment. Among organisational factors, learning might play a vital role. It is well documented by researchers that to be successful, organisations must not only process information but also create new information and knowledge (Inkpen and Dinur 1998). Each foreign or joint 
venture partner has knowledge that, at least part, should be considered valuable by the other partner(s). Hence, there can be a significant payoff in co-operating in knowledge creation, which could strengthen and reinforce a company's competitive strategy. Therefore, this makes it possible for joint venture partners not only to adapt, but also to transform through mutual learning. Therefore, it can be assumed that foreign and joint venture companies have provided a supportive environment in which both partners are engaged in learning to create more effective organisational context.

\section{Conclusion}

The intellectual origin and justification for the study was derived from the changing nature of formal MD processes in use and to describe the situation in Sri Lanka. The results of the investigation revealed differences in HR managers' responses and managers' responses for providing and experiencing formal MD processes. Further investigations revealed that not all HR managers actively engage in the provision of different formal MD processes. Instead, development processes such as on-the-job methods, job redesign methods and self- development methods are solely provided by the heads of the departments within their departments without having any specific organisation led MD initiative. However, in the companies that maintain certain level of consistency in providing these formal MD processes, either with or without the initiation of the HR managers, managers have experienced those in daily organisational life. Therefore, the findings of the study imply a contrast to the Sri Lankan literature that companies use more off-the-job processes (see- Jayaratna, 1996).

The influences of globalisation, requirements of foreign buyers, international standards, etc make Sri Lanka not detached from the rest of the world, which they might have had a few decades ago. On the other hand, as foreign investors have knowledge that, at least part, should be considered valuable by the other partner (s). Hence, there can be a significant payoff in co-operating in knowledge creation, which could strengthen and reinforce a company's competitive strategy. In this sense, foreign and joint venture investors could have brought into Sri Lanka not only "hardware" such as modern plans and equipment, but also "software" including MD systems and practices.

Several researchers emphasise the need of developing frameworks in MD field for the development of theoretical knowledge. Noon (1993) said that until research is conducted that tests specific hypotheses arising from the ideas, they remain helpful 'maps' rather than rigorous models. Therefore, this study attempted to add knowledge to an already existing body of knowledge on international MD practices to provide a solution to the empirical problem of the absence of coherent and exploratory frameworks for testing hypothesis by successfully integrating several dimensions of MD under scrutiny. Further, the study placed an interest in and emphasis on identifying the significance of the ownership type of the companies on the practices of MD in Sri Lanka. The design of the study made it possible to generalise some of the findings in a broader perspective to strengthen an already existing body of knowledge on international HRD/MD practices under export-led industrialisation strategy. 
However, Hofstede (1993) has shown that concepts of HRM and HRD are both countries specific. On one hand, the concepts of HRD would never have been invented in Asia; it comes as a foreign idea, to be adapted to the different local situations (Hofstede 1993). On the other hand, though the countries move fast, old values do not disappear overnight, and often survive in new settings; the systems of management must still respect continuity with old values and traditions. As the arguments leading up to the theory suggest that there is a two-way learning between the local and the foreign management, in depth analysis of MD systems could lead to not only find specific areas of learning from foreigners to locals but also the other way round. Therefore, in the Sri Lankan context, this emphasises the need of further in depth case studies of comparative analysis. Further, while it is quite feasible that all the formal MD processes may not apply in different cultures, it is important to hypothesize the role of culture in influencing the differences across nations/cultures. As this investigation does not present any culture-based rationale for expecting differences between what might be expected to happen in the West or other Asian countries that is different from what might be expected to happen in Sri Lanka. All these open areas of further research.

\section{References}

Armstrong, M. (1999), A Handbook of Human Resource Management Practice (7 ed.), London: Kogan Page.

Avery, G., Everett, A., Finkelde, A., and Wallace, K. (1999), Emerging Trends in Australian and New Zealand Management Development Practices in the Twentyfirst Century, Journal of Management Development, 18(1), pp 94-108.

Beach, D. S. (1975), Personnel: The Management of People at Work (3 ed.), London: Macmillan Publishing Company Inc.

Beechler, S., and Yang, J. Z. (1994), The Transfer of Japanese-Style Management to American Subsidiaries: Contingencies, Constraints, and Competencies, Journal of International Business Studies, 25(3), pp. 467-492.

Board of Investment of Sri Lanka (a), Make it in Sri Lanka: Business and Investment Environment, Colombo: BOI.

Board of Investment of Sri Lanka (b), Make it in Sri Lanka: Labour Standards and Relations, Colombo: BOI.

Board of Investment of Sri Lanka. (2000a), Garment sector: Garment Factories in Commercial Operation (1978 to 2000, October), Colombo: BOI, Research and Documentation Dept.

Board of investment of Sri Lanka. (2000b), Garment Sector: General Details of Garment Factories in Commercial Operation till 2000, October, Colombo: BOI, Research and Documentation Dept.

Bournois, F. (1992), The Impact of 1993 on Management Development In Europe (Changes Affecting Middle Managers in The EC), International Studies of Management and Organisation, Spring, 22(7), pp. 7-30.

Bournois, F., and Metcalfe, P. (1991), 'Human Resource Management of Executives in Europe: Structures, Policies and Techniques', in C. Brewster and S. Tyson (Eds.), International Comparison in Human Resource Management. London: Pitman. 
Brace, N., Kemp, R., and Snelger, R. (2000), SPSS for Psychologists: A Guide to Data Analysis Using SPSS for Windows, version 8, 9, and 10, London: Macmillan Press.

Bryman, A., and Cramer, D. (2001), Quantitative Data Analysis with SPSS Release 10 for Windows: A Guide for Social Scientists, East Sussex: Routledge.

Central Bank of Sri Lanka. (1998), Economic Progress of Independent Sri Lanka: 19481998, Colombo: Central Bank of Sri Lanka.

Central Bank of Sri Lanka. (2000), Central Bank Annual Report 2000, Retrieved 14/01/2002, 2002, from http://www.lanka.net/centralbank

Chandratileke, K. L. (1997), Managerial Value Orientations and Labour Management Relations; A Study of Export Manufacturing Firms in Sri Lanka, Institute of Social Studies, Hague.

Chen, M. (1995), Asian Management Systems: Chinese, Japanese and Korean Styles of Business, London: Routledge.

Chinniah, C. S. (1986), History of Administrative Training in the Public Sector of Sri Lanka. Colombo: SLIDA.

Cunningham, J. B., Debrah, Y. A., and Petzall, S (1996), 'Manufacturing Management Practices of Japanese Subsidiaries in Singapore', Industrial Management and Data Systems, 96(7), pp. 3-17.

Delaney, J. T., and Huselid, M. A. (1996), The Impact of Human Resource Management Practices on Perceptions of Organisational Performance, Academy of Management Journal, 39(4), pp. 949-969.

Department of National Planning (1992), Public investment 1992-1996, Colombo: Ministry of Policy Planning and Implementation, Department of National Planning.

Fonseka, A. T., and Fonseka, D. (1998), Garment Industry of Sri Lanka: Challenges and Responses, Sri Lanka Journal of Management, July-December, 3(3\&4), pp. 249291.

Fonseka, W. R. F. (1998), A Study of the Factors that Enhance the Transfer of Skills from the Trainers to the Trainees, University of Sri Jayawardenapura, Postgraduate Institute for Management, Colombo.

Griffith, D. A., Zaybek, A. Y., and O' Brien, M. (2001), Knowledge Transfer as a Means for Relationship Development: A Kazakhstan-Foreign International Joint Venture Illustration, Journal of International Marketing, 9(2), pp. 1-18.

Gunawardana, D. P. (1999), The Human Resources Needs of the Apparel Industry: Sri Lanka Experience, Textile and Apparel (a publication of Textile Training and Services Centre, Sri Lanka), April-June, 2(3), pp. 10-15.

Handy, C. (1987), The Making of Managers: A Report on Management Education, Training and Development in the USA, West Germany, France, Japan and the UK, London: National Economic Development Office.

Henderson, R., Sutherland, J., and Turley, S. (2000), Management development in small business: A sub-regional examination of practice, expectation and experience, Regional Studies, February, 30(1), pp. 43-61. 
Hofstede, G. (1993), 'The Applicability of McGregor's Theories in South East Asia', In P. Bunt and D. Richards (Eds.), Readings in Management, Organisation and Culture in East and South East Asia, Darwin, Australia: NTU Press.

Huczyanski, A. (1983), Encyclopaedia of Management Development Methods, England: Gower Publishing Co.

Ichiowski, C., Kochan, T., Levine, D., Olson C. and Strauss, G. (1996), 'What works at work: overview and assessment', Industrial Relations. 35(3), pp. 299-333.

Inkpen, A. C., and Beamish, P. W. (1997), Knowledge, Bargainning Power and International Joint Venture Stability, Academy of Management Review, 22(1), pp. 177-202.

Inkpen, A. C., and Dinur, A. (1998), Knowledge Management Processes and International Joint Ventures, Organisation Science, 9(4), pp. 454-468.

Institute of Management (1994), Management Development to the Millennium: The Taylor Working Party Report, Corby: Institute of Management

Jayaratna, M. N. J. (1996), Emerging Trends in Human Resource Management in Sri Lanka, Lanka Business Week, May-June, 3, pp. 3-6.

Karunatilake, A. G. N. (1999), The WTO and the Textile and Apparel Industry of Sri Lanka, Economic Review (a publication of Peoples Bank of Sri Lanka), 25(3\&4), pp. 2-7.

Kerr, C., Dunlop, J., Harbison, J., and Myers, C., (1960), Industrialisation and Industrial Man, New York: Oxford University Press.

Knoke, D., and Kalleberg, A. C. (1994), 'Job Training in US Organisations', American Sociological Review, 59, pp. 537-546.

Laburn, P. (1994), The Quintessential New South African Organisation, Human Resource Management, July, pp 14-16.

Lawler, J. L., Jain, H. C., Ratnam, C. S. V., and Atmiyanandana, V. (1995), Human Resource Management in Developing Economies: A comparison of India and Thailand, The International Journal of Human Resource Management, 6(2), pp. 319-346.

Liu, S., and Vince, R. (1999), The Cultural Context of Learning in International Joint Ventures, The Journal of Management Development, 18(8), pp. 666-675.

Lyles, M. A., and Salk, J. E. (1996), Knowledge Acquisition from Foreign Parents in International Joint Ventures: An Empirical Examination in the Hungarian Context, Journal of International Business Studies, 27(5), pp. 877-904.

Marsick, V. L., and Watkins, K. E. (1997), Lessons from Informal and Incidental Learning. In J. Burgoyne and M. Reynolds (Eds.), Management Learning: Integrating Perspectives in Theory and Practice, London: Sage Publications.

Minks, A. L., and Withana, R. M. (1977), Management Training in Sri Lanka: A Brief Study of the Public Sector, Colombo: Academy of Administrative Studies.

Mole, G. (2000), Managing Management Development, Buckingham: Open University Press.

Mumford, A. (1997), Management Development: Strategies for Action, London: IPM.

Mumford, A., Robinson, G., and Stradling, D. (1987), Developing Directors: The Learning Processes, Sheffield: Manpower Services Commission. 
Nanyakkara, G. (1992), Culture and management in Sri Lanka, Colombo: University of Sri Jayawardenapura, Postgraduate Institute for Management.

Naylor, D. M. (2000), Should Western Managers be Encouraged to Adopt JMPs? Employee Relations, 22(1\&2), pp. 160-175.

Nichols, T. (1986), The British worker question: a new look at workers and productivity in manufacturing, London: RKP.

Olian, J. D., Durham, C. C., Kirstoff, A. L., Brown, K. G., Pierce, R. M., and Kunder, L. (1998), Designing Management Training and Development for Competitive Advantage: Lessons from the Best, Human Resource Planning, March, 21(1), pp. 20-32.

Peel, M. (1984), Management Development and Training, London: British Institute of Management.

Romiszowski, A. J. (1990), Trends in Corporate Training and Development. In M. Mudler, A. J. Romiszowski and P. C. Van Der Sijde (Eds.), Strategic Human Resource Development, Amsterdam: Swets \& Zeitlinger Met Iit. opg.

Runyon, R. P., Coleman, K. A., and Pittenger, D. J. (2000), Fundamentals of Behavioural Statistics (9 ed.), Boston: McGraw Hill Companies.

Russell, J. S., Torborg, J. R., and Powers, M. L. (1985), 'Organisational Performance and Organisational Level Training and Support', Personnel Psychology, 38, pp. 849863.

Schein, E. H. (1986), 'A Critical Look at Current Career Development in Organisations', in D. T. Hall (Ed.), Career Development in Organisation, San Francisco: JosseyBass.

Schuler, R. S. (2001), Human Resource Issues and Activities in International Joint Ventures, The International Journal of Human Resource Management, 12(1), pp. $1-52$.

Senanayake, S. (2001), Apparel Industry after Expiry of MFA, Sri Lanka Exporter (a publication of the National Chambers of Exporters of Sri Lanka), March-May, 33, pp 49-52.

Sparrow, P., Schuler, R., and Jackson, S. E. (2000), Convergence or Divergence: Human Resource Practices and Policies for Competitive Advantage Worldwide, In M. Mendenhall and G. Oddou (Eds.), Readings and Cases in International Human Resource Management (3 ed.): South-Western Collage publishing.

Storey, J., Edwards, P., and Sisson, K. (1997), Managers in the Making: Careers, Development and Control in Corporate Britain and Japan, London: Sage Publications.

Taylor, B. (2001), The Management of Labour in Japanese manufacturing Plants in China, International Journal of Human Resource Management, 12(4), pp. 601-620.

Tennakoon, R. (1999), Apparel Industry: The Future Scenario, Economic Review (a publication of Peoples Bank of Sri Lanka), 25(3\&4), pp. 8-10.

Textile Training and Services Centre (TT\&SC) (1999), Vocational Education and Training Plan for Garment Industry, Colombo: Ministry of Vocational Training, Tertiary and Vocational Education Commission. 
Thompson, A., Mabey, C., and Storey, J. (1998), The Determinants of Management Development: Choice or Circumstance? International Studies of Management and Organisation, Spring, 28(1), pp. 91-114.

Ulrich, D., and Lake, D. (1990), Organisational Capability: Competing From the Inside/Out, New York: John Wiley.

Veblen, T. (1954), 'The opportunity of Japan', in Ardzrooni, L. (Ed), Essays in our changing order, New York: Viking Press (Reprinted from Journal of Race Development, 6, July, 1915).

Waidyanatha, W. G. S. (1999), Sri Lanka Apparel Industry: In the Midst of Challenge, Economic Review (a publication of Peoples Bank of Sri Lanka), 25(3\&4), pp. 2-7.

Whitley, R. (1994), Business Systems in East Asia: Firms, Markets, and Societies. London: Sage Publications Ltd.

Wijetunga, M. D. K. H. (1992), Training and Development in the Department of Post, University of Sri Jayawardenapura, Postgraduate Institute for Management, Colombo.

Wijewardena, H., and Wimalasiri, J. S. (1996), In Search of an Asian Style of Management, Sri Lanka Journal of Management, April-June, 1(2), pp. 125-140.

Yin, R. K. (1994), Case Study Research: Design and Methods, California: Sage Publications. 